\section{Predicting Risk of European Corn Borer Infestation in Sweet Corn Based on Harvest Date}

\author{
Steve M. Spangler ${ }^{3}$, Dennis D. Calvin ${ }^{1}$, Joe Russo ${ }^{2}$, and \\ Jay Schlegel ${ }^{2}$
}

AdDITIONAL INDEX WORDs. Ostrinia nubilalis, Zea mays, prediction maps, spatial mapping, integrated pest management

SUMMARY. Infestation of sweet corn (Zea mays) at harvest by european corn borer (Ostrinia nubilalis) was examined in 16 hybrid/harvest date combinations from 1994 through 1996 in central Pennsylvania. Two general periods of sweet corn ear infestation levels were observed. Infestations, expressed as proportion of ears infested, were $0.11(11 \%)$ or lower in 10 of 11 plots harvested from 21 July to 23 Aug., whereas they were noticeably higher (30\%-88\%) in September and early October. Infestations expressed as larvae per ear showed the same temporal pattern. A nonlinear (sigmoidal) relationship was found between degree-days from 1 Jan. and proportion of ears infested. The higher infestations were caused by the secondgeneration larvae of the bivoltine ecotype. Based on these relationships, a riskprediction system is proposed that anticipates, at planting, harvest infestation by using predicted harvest dates of sweet corn, european corn borer life stages, and infestation levels. Examples are presented for multiple plantings and hybrids for a specific site and a landscape (Pennsylvania). The risk prediction system we propose will allow growers to anticipate the risk of ear infestations at planting time, thus providing predictions that would help with management decisions.

S weet corn is a high-value crop important to the agricultural economy of the northeastern and midwestern United States. In 2007, there were about 324,000 acres of sweet corn grown in this region, and the value was about $\$ 1186$ per acre (U.S. Department of Agriculture, 2008). Because of this high value, and because consumer tolerance for insect infestation is typically very low, sweet corn production can require high insecticide and labor inputs (Dively, 1996; Flood et al., 1995) to prevent harvest infestation and damage by european corn borer, corn earworm (Helicoverpa zea), and fall armyworm (Spodoptera frugiperda).

We are grateful for the assistance provided by Paul Rebarchak, Tim Grove, Deb Lehto, Nathan Piekelek, Scott Lynn, Suzy Dreibelbis, Chris Engle, Dan Ranshaw, and Sue Lueloff. Bob Kotch and Doug Plaisted (Rogers ${ }^{\circledR}$ Seed Company) provided seed and horticultural information. Two anonymous reviewers provided helpful comments.

Department of Entomology, The Pennsylvania State University, 501 Agricultural Sciences Building, University Park, PA 16802

${ }^{1}$ In compliance with Penn State policy, the author Dennis Calvin is acknowledging a significant financial interest in ZedX, Inc.

${ }^{2}$ ZedX, Inc., Information Technology, 369 Rolling Ridge Drive, Bellefonte, PA 16823

${ }^{3}$ Corresponding author. E-mail: smspangler@att.net
Producers of fresh market sweet corn plant on a succession of dates to provide a continuous supply of produce for the market throughout the growing season (Ferro and FletcherHowell, 1985), resulting in a wide range of harvest dates. The practice of planting sweet corn in a succession of plantings ("staggered plantings") is also used in processing sweet corn production to meet demand (Pike, 2003). These staggered planting and harvest dates, plus large seasonal variation in european corn borer seasonal activity, lead to large variability in european corn borer infestation levels. During periods of high european corn borer infestations, recommendations suggest the application of an insecticide every 4 days during the "silking" stages to prevent ear damage (Dively, 1996). This can result in three to five insecticide applications per planting to control this pest.
Conversely, these recommendations also suggest that no spray is needed when insect populations, as indicated by egg density or moth catches in traps, are sufficiently low.

Studies have shown that european corn borer infestation in the ear and damage at harvest in sweet corn varies somewhat predictably according to harvest date. Ferro and FletcherHowell (1985) found a bimodal pattern of infestation levels, with plots harvested before 1 Aug. having moderate european corn borer infestations, the plot harvested on 4 Aug. having almost no infestation, whereas those harvested after $10 \mathrm{Aug}$. and into September had much higher infestation levels. Andreadis (1988) also found similar results in Connecticut, with low infestations found on a 12 Aug. harvest date, and much higher infestations in September and October harvests. These studies indicated infestation patterns caused by the bivoltine ecotype (Mason et al., 1996) of european corn borer.

Temporal patterns of european corn borer larval infestations have shown somewhat different patterns where the univoltine ecotype and bivoltine ecotypes are present, such as in New York. For instance, Shelton (1986) examined european corn borer damage for processing sweet corn in New York. In 1983, he found that european corn borer damage was consistently higher in August than in September. In contrast, in 1982 infestations were higher in September compared with August. These observations may have indicated that infestations occurred from univoltine (which occur from late July to late August) and second-generation bivoltine european corn borer larvae (which occur from mid-August into September). Mixes of both voltine ecotypes have been documented in New York (Eckenrode et al., 1983).

There are various approaches to monitoring and predicting european corn borer infestation in sweet corn.

\begin{tabular}{llll}
\hline $\begin{array}{l}\text { Units } \\
\begin{array}{l}\text { To convert U.S. to SI, } \\
\text { multiply by }\end{array}\end{array}$ & U.S. unit & SI unit & $\begin{array}{l}\text { To convert SI to U.S., } \\
\text { multiply by }\end{array}$ \\
\hline 0.4047 & acre(s) & ha & 2.4711 \\
0.3048 & $\mathrm{ft}$ & $\mathrm{m}$ & 3.2808 \\
2.54 & inch $(\mathrm{es})$ & $\mathrm{cm}$ & 0.3937 \\
1.6093 & mile(s) & $\mathrm{km}$ & 0.6214 \\
$\left({ }^{\circ} \mathrm{F}-32\right) \div 1.8$ & ${ }^{\circ} \mathrm{F}$ & ${ }^{\circ} \mathrm{C}$ & $\left(1.8 \times{ }^{\circ} \mathrm{C}\right)+32$
\end{tabular}


European corn borer is relatively easy to monitor in its egg, larval, or moth stages, thereby facilitating in-season management programs that can be used to evaluate the risk of crop infestation (Dively, 1996; Flood et al., 1995 ). Egg mass scouting can be made more efficient with the use of larval stage-structure models, which optimize the timing of in-field egg scouting programs (Calvin et al., 1986). Simpler degree-day models have also been used that predict peak activity of moth flights based on degree-day accumulation (Despins and Roberts, 1984), and development rates based on degree-days can be used to predict occurrence of various life stages of european corn borer (Bessin, 2003; Glogoza and Boetel, 2005; Tollefson and Calvin, 1994). Finally, current monitoring results, historical records, and predictive aspects can be integrated for practitioners to readily access and use (Fleischer, 2003; Holmstrom et al., 2001; Hutchison and Wold, 2003).

These approaches use growingseason activities to monitor and predict the occurrence of european corn borer in sweet corn at harvest. However, no systematic attempt has been made to predict the risk of harvest infestation by european corn borer at the time of planting. Development of an at-planting prediction system would increase the ability of growers to anticipate harvest infestation, and, therefore, needed management resources (i.e., scouting, labor, insecticides, biological control, and extra cost of transgenic sweet corn) at planting time. Integration of degreeday models that predict harvest date based on corn development (Arnold, 1974; Ritchie et al., 1992), predictions of european corn borer stages present at the time of harvest (Bessin, 2003; Glogoza and Boetel, 2005; Tollefson and Calvin, 1994), and use of landscape prediction techniques (Royer et al., 1989) could improve management of european corn borer in sweet corn.

The goal of this research was to develop a prediction system of sweet corn ear infestation risk by european corn borer larvae for various planting and harvest dates by integrating european corn borer and sweet corn developmental rates. Using documented european corn borer infestation levels across a range of harvest dates from central Pennsylvania, these infestation levels and harvest dates were related to sweet corn developmental rates. Using this information, a method is proposed to assess the risk of european corn borer harvest infestation for an individual site and across a landscape at planting time.

\section{Materials and methods}

Field studies. All field studies were conducted at the Russell E. Larsen Research Farm, located about 10 miles west of University Park, PA. Moth flights were monitored with a standard black light trap (Dively, 1996; Mason et al., 1996) within 1 mile of the research site. These black light captures indicated a mix of bivoltine and univoltine european corn borer, although the moths of the bivoltine ecotype were more prevalent in 1995 and 1996 (Spangler and Calvin, 2000).

To evaluate larval infestation patterns of european corn borer, three studies were conducted between 1994 and 1996. A wide range of planting dates and years were used to give a wide range of harvest dates and infestation levels, and to simulate the planting patterns of successionally planted sweet corn production. Seed was provided by Rogers ${ }^{\circledR}$ (Boise, ID). In 1994, four successive plantings were established ( 5 May, 1 June, 20 June, and 8 July) of a 78-d, intermediate-stature, sweet corn hybrid ['Krispy King'; 909 degreedays from planting to harvest (base 10 $\left.{ }^{\circ} \mathrm{C}\right), 1637$ degree-days (base $50{ }^{\circ} \mathrm{F}$ ) ] in a 1-acre field, previously in alfalfa (Medicago sativa) in 1993. Plots were arranged in a randomized completeblock design, with planting date treatments blocked four times. Each plot was $30 \times 30 \mathrm{ft}$, with 12 rows spaced 30 inches apart, and with a plant density of 26,000 plants/acre.

In 1995, the same 1 -acre field was used, plus an adjacent 1 -acre field that had previously been in alfalfa. This experiment included four planting dates (28 Apr., 22 May, 7 June, and 3 July) of a 67-d, short-stature, sweet corn ['Kandy Kwik'; 776 degree-days (base $10{ }^{\circ} \mathrm{C}$ ), 1397 degree-days (base $50{ }^{\circ} \mathrm{F}$ )], and four planting dates (28 Apr., 22 May, 7 June, and 3 July) of an 88-d, tallstature, sweet corn ['Silver Queen'; 1031 degree-days (base $10{ }^{\circ} \mathrm{C}$ ), 1855 degree-days (base $\left.50{ }^{\circ} \mathrm{F}\right)$ ]. Plot dimensions, plant spacing, and plant density were identical to those used in 1994. To avoid confounding of these 1995 treatments because of different cropping histories, two of the blocks were positioned in the field that had been in corn in 1994, and two were in the field that had been in alfalfa in 1994.

In 1996, the same 1 -acre field was used that had previously been in alfalfa in 1994 and followed by corn in 1995 . The experiment had four planting dates (13 Apr., 25 Apr., 20 May, and 4 June) of a 78-d, intermediate-stature, sweet corn ['Primetime'; 909 degree-days (base $10{ }^{\circ} \mathrm{C}$ ), 1637 degree-days (base $50{ }^{\circ} \mathrm{F}$ )]. Plots were arranged in a randomized complete block design, with treatments (planting dates) blocked four times. Each plot was $40 \times 40 \mathrm{ft}$, with 16 rows spaced 30 inches apart. Planting density was the same as in 1994 and 1995.

No plot was sprayed with foliar insecticides. To manage weeds, all plots were treated with various commercial herbicides at labeled rates, and were cultivated as necessary. In 1994, labeled rates of herbicides were applied on 2 May (EPTC and metolachlor) and 10 June (nicosulfuron and nonionic surfactant). In 1995, they were applied on 3 May (metolachlor and atrazine). In 1996, they were applied on 25 Apr. (atrazine, simazine, and metolachlor) and 6 June (nicosulfuron). In plots that were in corn the previous year, a soil insecticide with no systemic activity (tefluthrin) was used at the labeled rate at planting time to prevent injury from corn rootworm (Diabrotica virgifera virgifera and Diabrotica longicornis barberi) and black cutworm (Agrotis ipsilon). To prevent frost damage, all plots planted before May were covered with a spun-bonded polyester rowcover until the three-leaf stage.

Ten successive plants in two rows of each plot (20 total plants per plot) were flagged and searched twice weekly for egg masses beginning at the three-leaf stage, continuing until senescence (1994-95) or harvest (1996). At harvest, single sweet corn ears from 10 (1994) to 20 (1995-96) plants per replicate were examined for larvae. Larval infestations were calculated as larvae per ear and proportion of ears infested (proportion having one or more larvae per ear). Means of larval infestations for each hybrid/ 
planting date combination were calculated as means of the four replicates.

Temperature data for the site were provided by ZedX, Inc. (Boalsburg, PA) using interpolated estimates. Daily heat unit accumulations (degree-days) were calculated by using the daily minimum and maximum temperatures, using the formula (\{maximum temperature + minimum temperature $\} / 2)$ - base threshold (Angel, 2008). Sweet corn and european corn borer degree-days were calculated with a base threshold of $10{ }^{\circ} \mathrm{C}\left(50.0^{\circ} \mathrm{F}\right)$ and upper threshold of $30^{\circ} \mathrm{C}\left(86.0^{\circ} \mathrm{F}\right)$.

Statistical analyses and MODEL PREDICTIONS. Nonlinear (sigmoidal) regressions were used to express the relationship between degree-days from 1 Jan. and european corn borer infestation levels of various sweet corn harvest dates (TableCurve ${ }^{\circledR} 2 \mathrm{D}$; SPSS Inc., Chicago). Climate data were provided by the National Climatic Data Center. Landscape maps of various aspects of plant and insect development based on degree-day accumulations were provided by ZedX, Inc. These maps were produced with $1 \mathrm{~km}^{2}$ resolution, using optimal interpolation with correction for elevation.

\section{Results and discussion}

TEMPORAL OVIPOSITION PATTERNS. Oviposition occurred from early June to early September (Fig. 1). Peak oviposition of the bivoltine first

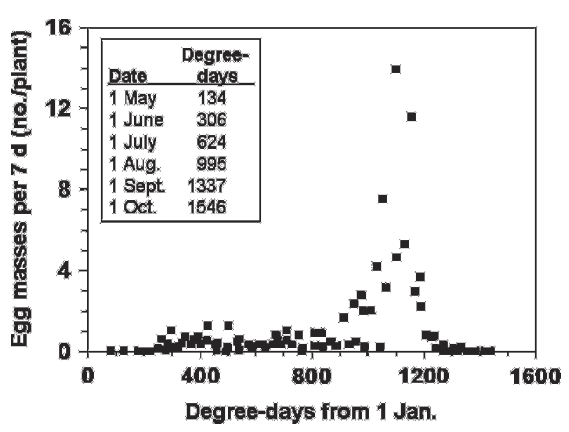

Fig. 1. European corn borer oviposition rates on sweet corn in 1994-96. Vertical axis shows mean oviposition rates across all plantings from V3 [three leaf collars visible (Ritchie et al., 1992)] to 1-week postharvest according to degree-day accumulations from 1 Jan. [base $10{ }^{\circ} \mathrm{C}$ $\left.\left(50.0{ }^{\circ} \mathrm{F}\right)\right]$. Text box indicates the degree-days accumulated at the beginning monthly day, May to October (3-year 1994-96 average). generation European corn borer occurs at $\approx 473$ degree-days from 1 Jan. (base $10{ }^{\circ} \mathrm{C}$ ); peak oviposition of the bivoltine second generation occurs at $\approx 1173$ degree-days from 1 Jan. (adapted from Bessin, 2003); and peak oviposition of the univoltine ecotype occurs at $\approx 667$ degree-days from 1 Jan. (adapted from Glogoza and Boetel, 2005). Therefore, these oviposition patterns indicate the oviposition of first generation bivoltine, univoltine, and second-generation bivoltine european corn borer. Moth flights from the study site during the same time period also indicated similar patterns (Spangler and Calvin, 2000). However, most oviposition appeared to occur during the second-generation bivoltine period (after $\approx 900$ degree-days; Fig. 1). Therefore, most of the resulting larval infestations were caused by the second-generation ecotype.

EUROPEAN CORN BORER DAMAGE LEVEL AND TIME OF HARVEST. Plots were harvested from 21 July to 5 Oct. across all 3 years (Table 1 ). Ear infestation levels ranged from 3\% to 19\% between 21 July and 23 Aug. Excluding the 14 Aug. 1995 harvest date (19.5\%), infestation levels were relatively low during this period, ranging from $2.5 \%$ to $11.3 \%$. In contrast, sweet corn harvested from 1 Sept. to 5 Oct. had noticeably higher infestation levels, ranging from $30 \%$ to $85 \%$. Infestation expressed as larvae per ear paralleled patterns of proportion of ears with larvae (Table 1) and the number of larvae per ear at harvest was highly correlated with the proportion of ears with larvae, having an $\mathrm{r}^{2}=1.0$ (Fig. 2).

These patterns of harvest dates and infestation levels parallel results found in other regions of the northeastern United States where the bivoltine european corn borer is the dominant ecotype. In a series of harvests from 22 July to 14 Sept., Ferro and Fletcher-Howell (1985) observed european corn borer-damaged ears of $2 \%$ to $7 \%$ in late July harvests. These levels dropped to $0.5 \%$ by 4 Aug., but then showed sharp increases after 10 Aug., peaking at $69 \%$ european corn borer-damaged ears on 14 Sept. Andreadis (1988) observed european corn borer damage levels of 0.02 larvae/ear with a 12 Aug. harvest, and 0.38 and 0.18 larvae/ear in the 3 Sept. and 9 Oct. harvests, respectively. These studies were done in areas with bivoltine european corn borer populations. In contrast, Shelton (1986) observed variability of european corn borer damage in August compared with September harvests. These variable observations may have reflected a mix of univoltine european corn borer populations, which have larval activity during August, and bivoltine populations, which have larval activity during September.

Table 1. Hybrid sweet corn harvest dates, cumulative degree-days from 1 Jan. at harvest, and european corn borer infestation levels at harvest for 16 planting dates in 1994-96 at Rock Springs Research Farm in central Pennsylvania.

\begin{tabular}{|c|c|c|c|c|c|}
\hline \multicolumn{2}{|c|}{ Harvest } & \multirow{2}{*}{$\begin{array}{l}\text { Degree-days } \\
10{ }^{\circ} \mathrm{C} \\
\text { from } 1 \mathrm{Jan} .\end{array}$} & \multirow{2}{*}{$\begin{array}{l}\text { Degree-days } \\
50{ }^{\circ} \mathrm{F} \\
\text { from } 1 \text { Jan. }\end{array}$} & \multirow{2}{*}{$\begin{array}{c}\text { Proportion of ears } \\
\text { infested } \\
(\text { mean } \pm S E)\end{array}$} & \multirow{2}{*}{$\begin{array}{c}\text { Larvae } \\
(\text { mean no./ } \\
\text { ear } \pm S E)\end{array}$} \\
\hline Year & Date & & & & \\
\hline 1995 & 21 July & 727 & 1309 & $0.113 \pm 0.052$ & $0.113 \pm 0.052$ \\
\hline 1995 & 31 July & 869 & 1564 & $0.108 \pm 0.074$ & $0.108 \pm 0.074$ \\
\hline 1996 & 6 Aug. & 891 & 1604 & $0.103 \pm 0.048$ & $0.103 \pm 0.048$ \\
\hline 1995 & 9 Aug. & 987 & 1777 & $0.033 \pm 0.019$ & $0.033 \pm 0.019$ \\
\hline 1994 & 10 Aug. & 975 & 1755 & $0.050 \pm 0.029$ & $0.050 \pm 0.029$ \\
\hline 1996 & 11 Aug. & 950 & 1710 & $0.043 \pm 0.028$ & $0.043 \pm 0.028$ \\
\hline 1995 & 14 Aug. & 1055 & 1899 & $0.195 \pm 0.080$ & $0.248 \pm 0.106$ \\
\hline 1996 & 15 Aug. & 988 & 1778 & $0.040 \pm 0.025$ & $0.050 \pm 0.035$ \\
\hline 1995 & 18 Aug. & 1117 & 2011 & $0.090 \pm 0.038$ & $0.090 \pm 0.038$ \\
\hline 1994 & 21 Aug. & 1088 & 1958 & $0.025 \pm 0.025$ & $0.025 \pm 0.029$ \\
\hline 1996 & 23 Aug. & 1082 & 1948 & $0.063 \pm 0.031$ & $0.125 \pm 0.063$ \\
\hline 1995 & 1 Sept. & 1273 & 2291 & $0.813 \pm 0.113$ & $1.285 \pm 0.298$ \\
\hline 1995 & 5 Sept. & 1306 & 2351 & $0.715 \pm 0.107$ & $1.000 \pm 0.213$ \\
\hline 1994 & 14 Sept. & 1261 & 2270 & $0.300 \pm 0.041$ & $0.375 \pm 0.048$ \\
\hline 1995 & 28 Sept. & 1441 & 2594 & $0.845 \pm 0.032$ & $1.573 \pm 0.161$ \\
\hline 1994 & 5 Oct. & 1372 & 2470 & $0.575 \pm 0.095$ & $0.675 \pm 0.025$ \\
\hline
\end{tabular}




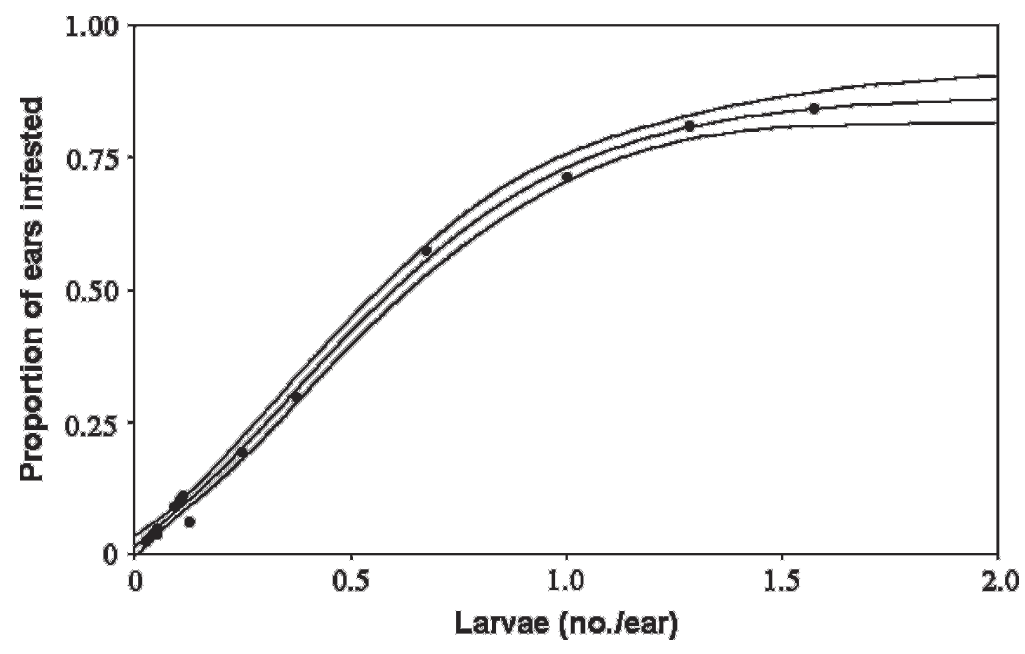

Fig. 2. Nonlinear (sigmoidal) regression of the relationship between european corn borer larvae/ear on sweet corn ears at harvest and proportion of sweet corn ears with larvae at harvest. The regression is $\mathrm{y}=\mathrm{a}+\mathrm{b} /\{1+\exp [-(\mathrm{x}-\mathrm{c}) / \mathrm{d}]\}$, where $\mathrm{a}=-0.250 \pm 0.108, \mathrm{~b}=1.120 \pm 0.127, \mathrm{c}=0.377 \pm 0.062, \mathrm{~d}=0.320 \pm 0.047$ (mean of parameter $\pm \mathrm{SE})$, mean square error $=0.0185, \mathrm{~F}=1446.84,(P<0.0001)$, $\mathrm{df}=1,15$, and $\mathrm{r}^{2}=0.996$. The predicted equation is represented by the middle line, with the $95 \%$ confidence intervals shown by the upper and lower lines.

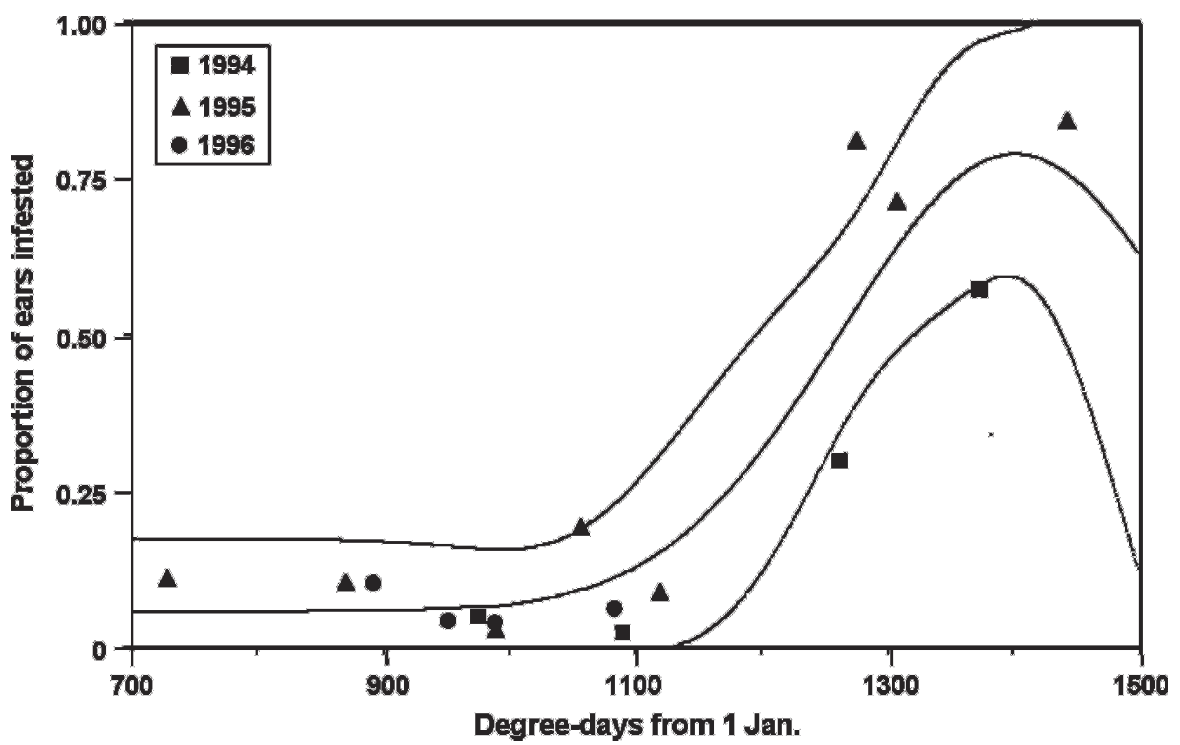

Fig. 3. European corn borer infestation levels (proportion of ears infested) of sweet corn ears related to predicted life stages based on degree-days [base $10{ }^{\circ} \mathrm{C}\left(50.0^{\circ} \mathrm{F}\right)$ ] accumulated from 1 Jan. Each point represents one hybrid/harvest date combination, 1994-96. The nonlinear (sigmoidal) equation is $\mathbf{y}=\mathbf{a}+\mathbf{b} \times$ $\left(\exp \left\{-0.5[(\mathrm{x}-\mathrm{c}) / \mathrm{d}]^{2}\right\}\right)$, where $\mathrm{a}=0.0589 \pm 0.0532, \mathrm{~b}=0.7311 \pm 0.0965, \mathrm{c}=$ $1402.5667 \pm 47.6144, \mathrm{~d}=139.4216 \pm 51.1160($ mean of parameter $\pm \mathrm{SE}), \mathrm{r}^{2}=0.85, \mathrm{~F}$ $=22.5,(P<0.0005)$, and $\mathrm{df}=1,15$. The predicted values are represented by the middle line, with the $90 \%$ confidence intervals shown by the upper and lower lines.

INFESTATIONS, DEGREE-DAYS, AND PREDICTED EUROPEAN CORN BORER LIFE STAGES. Infestation levels, grouped according to degree-days accumulated from 1 Jan. (base $10^{\circ} \mathrm{C}$ ), appeared to show two general groupings (Table 1). Except for the 14 Aug. $1995(19.5 \%$ infestation at 1055 degree-days), infestation levels were $11 \%$ or lower from 727 to 1117 degree-days. After this, they were noticeably greater $(30 \%$ to $85 \%$ ) from 1261 to 1441 degree-days. These infestation levels were correlated with degree-days from 1 Jan., with the proportion of ears infested with european corn borer larvae at harvest (y-variable) expressed as a nonlinear (sigmoidal) function of degree-days from 1 Jan. (x-variable), with an $\mathrm{r}^{2}=$ 0.85 (Fig. 3).

According to published european corn borer development rates (Bessin, 2003; Glogoza and Boetel, 2005), the period of lower infestations (727-1117 degree-days; see Table 1) would likely have been the bivoltine ecotype at about the third instar larva of the first generation through about the egg stage of the second generation, and the univoltine ecotype would be present in its various larval stages. In contrast, the much higher infestations (1261-1441 degreedays) occurred after the fifth instar larva of the univoltine ecotype, and during the egg through fourth instar larvae of the second generation bivoltine ecotype. Thus, oviposition (Fig. 1) and larval infestation (Fig. 3) patterns indicated that most infestations were caused by the second-generation bivoltine ecotype.

In summary, our data indicate that infestation level at harvest, expressed as proportion of ears infested, was strongly related to the degreedays from 1 Jan. $\left(r^{2}=0.85\right)$, and that higher infestation levels were associated with predicted occurrence of larval stages of the second generation bivoltine ecotype (Fig. 3). This model was based on a data set from one site that encompassed 3 years, four hybrids, and a wide range of harvest dates. Based on this knowledge, the potential exists to predict european corn borer risk periods for more effective use of management tactics.

FARM-SPECIFIC AND LANDSCAPE PREDICTIONS OF EUROPEAN CORN BORER INFESTATIONS. Based on the relationships between degree-days from 1 Jan. and european corn borer infestation (Fig. 3), we propose a prediction system that may provide sweet corn growers with improved knowledge of which planting dates and harvest dates are more susceptible to european corn borer infestations at a given geographic locations. An example of several farm-specific predictions is shown in Table 2. Several sets of predictions are needed to assess the likelihood of european corn borer infestation at harvest shown in this table. First, degree-day accumulations can be used to predict harvest dates across a range of planting dates. 
Table 2. Predicted harvest dates, european corn borer degree-days, and european corn borer infestation levels (proportion of ears with one or more larvae + SD) for three simulated sweet corn hybrids planted on different dates. Harvest dates for the sweet corn hybrids are based on degree-day accumulation (base $10{ }^{\circ} \mathrm{C}$ ) from date of planting to harvest using 30 -year average (1976-2005) daily temperatures for Rock Springs Research Farm in central Pennsylvania. The proportion of ears infested at harvest $(\mathrm{y}=$ mean $\pm \mathrm{SE})$ is based on the nonlinear model $\mathrm{y}=\mathrm{a}+\mathrm{b} \times \exp \left\{-0.5[(\mathrm{x}-\mathrm{c}) / \mathrm{d}]^{2}\right\}$, where $\mathbf{a}=0.0589 \pm 0.0532$, $\mathrm{b}=0.7311 \pm 0.0965, \mathrm{c}=1402.5667 \pm 47.6144, \mathrm{~d}=139.4216 \pm 51.1160$ (mean of parameter $\pm \mathrm{SD})$, and $\mathrm{x}=\mathrm{european}$ corn borer degree-days (base $\left.10{ }^{\circ} \mathrm{C}\right)$, for that harvest date from 1 Jan. $(P<0.0005)$.

\begin{tabular}{|c|c|c|c|c|c|}
\hline \multirow[b]{2}{*}{ Hybrid } & \multirow[b]{2}{*}{ Events } & \multicolumn{4}{|c|}{ Planting date } \\
\hline & & 15 Apr. & 7 May & 1 June & 21 June \\
\hline \multirow[t]{2}{*}{ 67-d (776 degree-days) } & Harvest date & 25 July & 30 July & 13 Aug. & 2 Sept. \\
\hline & $\begin{array}{l}\text { Proportion of ears } \\
\quad \text { infested }(\text { mean }+\mathrm{SE})\end{array}$ & $0.059 \pm 0.054$ & $0.059 \pm 0.054$ & $0.064 \pm 0.071$ & $0.206 \pm 0.153$ \\
\hline & $\begin{array}{l}\text { Proportion of ears } \\
\quad \text { infested }(\text { mean } \pm \mathrm{SE})\end{array}$ & $0.060 \pm 0.060$ & $0.062 \pm 0.066$ & $0.123 \pm 0.122$ & $0.599 \pm 0.099$ \\
\hline \multirow[t]{2}{*}{ 88-d (1031 degree-days) } & Harvest date & 20 Aug. & 24 Aug. & 12 Sept. & 8 Oct. $^{z}$ \\
\hline & $\begin{array}{l}\text { European corn } \\
\text { borer degree-days }\end{array}$ & 1040 & 1078 & 1221 & 1307 \\
\hline
\end{tabular}

${ }^{2}$ Simulated harvest done for this hybrid done before predicted date because no further degree-days were accumulated.

As an example, for three hybrids of different maturities planted on 1 June, Table 2 shows that a 67-d hybrid planted on that date would have a predicted harvest date of 13 Aug., a $78-\mathrm{d}$ hybrid would be harvested on 26 Aug., and an 88-d hybrid would be harvested 12 Sept. Accumulated european corn borer degree-days from I Jan. can be calculated for those harvest dates. Those same hybrids and planting dates just discussed will result in 971, 1095, and 1221 european corn borer degree-days from l Jan., respectively. Finally, based on those european corn borer developmental degree-days, infestation levels can be predicted based on the harvestdate relationship shown in Fig. 3. Thus, using the same example, the 67-d hybrid planted on 1 June is predicted to have $6.4 \%$ ears infested on the 13 Aug. harvest date, the 76-d hybrid planted on the same day would have an infestation of $12.3 \%$ on the 26 Aug. harvest date, and the 88-d hybrid planted on the same day is predicted to have $37.2 \%$ ears infested on the 12 Sept. harvest date. Table 1 also indicates that eight of the 12 harvest dates would have harvest dates before the noticeable increases in infestation occurring at 1100 degree-days (Fig. 3).

The same concepts for farmspecific assessment of european corn borer infestation (Table 2; Fig. 3 ) can be used to make assessments across a landscape. For instance, given that a 78-d hybrid takes 909 degree-days to develop to harvest, landscape maps can be produced in which the projected harvest dates are estimated for 1 May (Fig. 4) and 15 June (Fig. 5) planting dates. For example, the 78 -d hybrid planted in the southeastern part of Pennsylvania on 1 May would have a projected harvest date in the third to fourth week of July (Fig. 4), whereas the same hybrid would have a projected harvest date of mid to late August if planted in the same region on 15 June (Fig. 5). Given the information on projected harvest dates shown in Figs. 4 and 5, a grower then might want to assess the risk of those harvest dates to infestation by european corn borer. Thus, Fig. 6 shows that the same southeastern region of Pennsylvania enters into the high european corn borer risk period, or about 1100 degree-days (see Fig. 3), from about 29 July to 17 Aug. Because fields that are planted 1 May would be harvested in late July in southeastern Pennsylvania (Fig. 4), they are probably at fairly low risk from second-generation bivoltine larvae. However, fields that are planted on 15 June are at much greater risk because they are projected to be harvested about 18 Aug. to 6 Sept.
(Fig. 5), which is well into the higher european corn borer risk period (Fig. 6).

Because the relationship between proportion of ears infested and degree-days from 1 Jan. was quite strong $\left(r^{2}=0.85\right.$; Fig. 3$)$ it is also possible that levels of infestation can be predicted. For instance, Fig. 7 predicts that plots harvested on 1 Sept. in central Pennsylvania would have only $0 \%$ to $29 \%$ ears infested, whereas infestation levels would be much higher in the southwestern and southeastern regions of the Pennsylvania.

IMPROVING PREDICTIONS OF EUROPEAN CORN BORER INFESTATIONS IN SWEET CORN. The technology and knowledge currently exists to predict sweet corn harvest dates from various planting dates, as well as european corn borer life stages likely to be present at various harvest dates (Calvin, 2007). The degree-day accumulations from planting to harvest for particular hybrids are readily available from seed companies, and daily minimum and maximum temperatures are readily available as long-term averages as well as being updatable as the growing season progresses. European corn borer life stages likely to be present at various harvest dates are also available (Bessin, 2003; Glogoza and Boetel, 2005; Tollefson and Calvin, 1994). Thus, this technology 


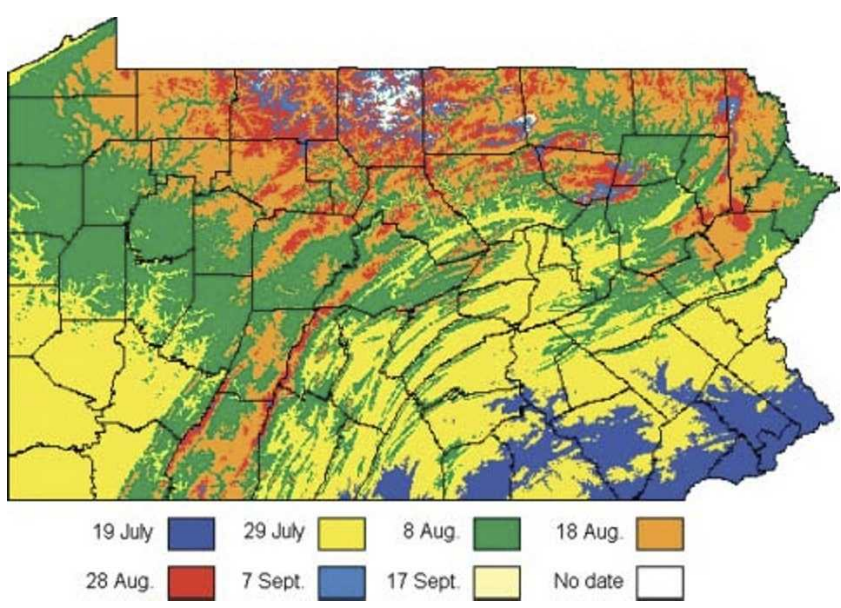

Fig. 4. Map showing predicted beginning calendar dates when a 78-d sweet corn hybrid $\{909$ degree-days from planting to harvest [base $\left.\left.10^{\circ} \mathrm{C}\left(50.0^{\circ} \mathrm{F}\right)\right]\right\}$ would be harvested throughout Pennsylvania, when planted on 1 May. Degree-day predictions are based on 30-year temperature averages.

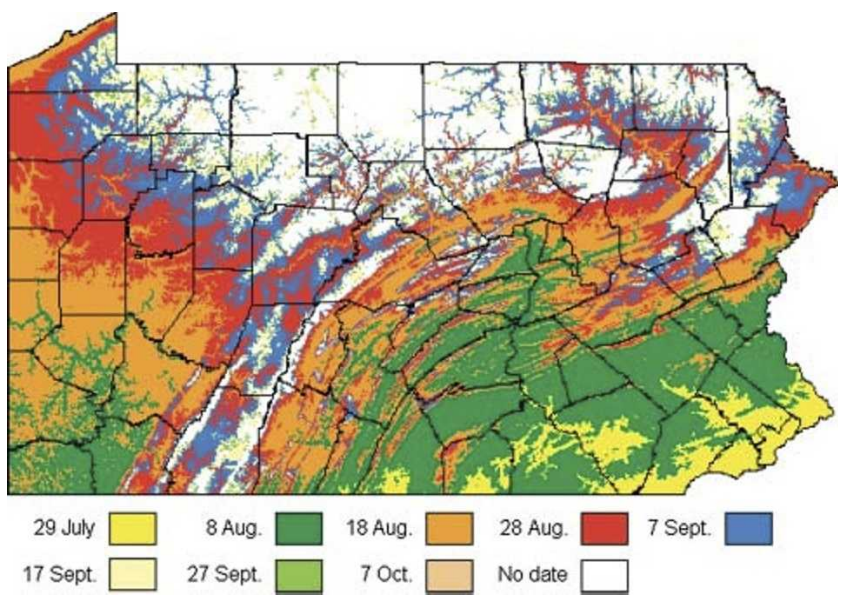

Fig. 6. Map showing beginning of risk period $(>12 \%$ infested ears) of second generation european corn borer infestation of sweet corn $\left\{1100\right.$ degree-days [base $10{ }^{\circ} \mathrm{C}$ $\left(50.0{ }^{\circ}\right.$ F) from 1 Jan. $\left.]\right\}$ across Pennsylvania, based on 30 year temperature averages.

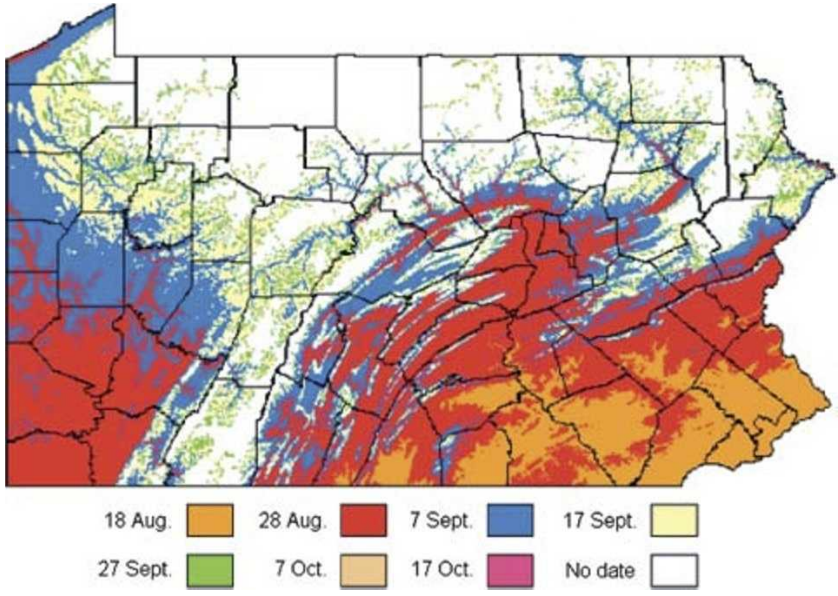

Fig. 5. Map showing predicted beginning calendar dates when a 78-d sweet corn hybrid $\{909$ degree-days from planting to harvest [base $\left.\left.10{ }^{\circ} \mathrm{C}\left(50.0{ }^{\circ} \mathrm{F}\right)\right]\right\}$ would be harvested throughout Pennsylvania, when planted on 15 June. Degree-day predictions are based on 30-year temperature averages.

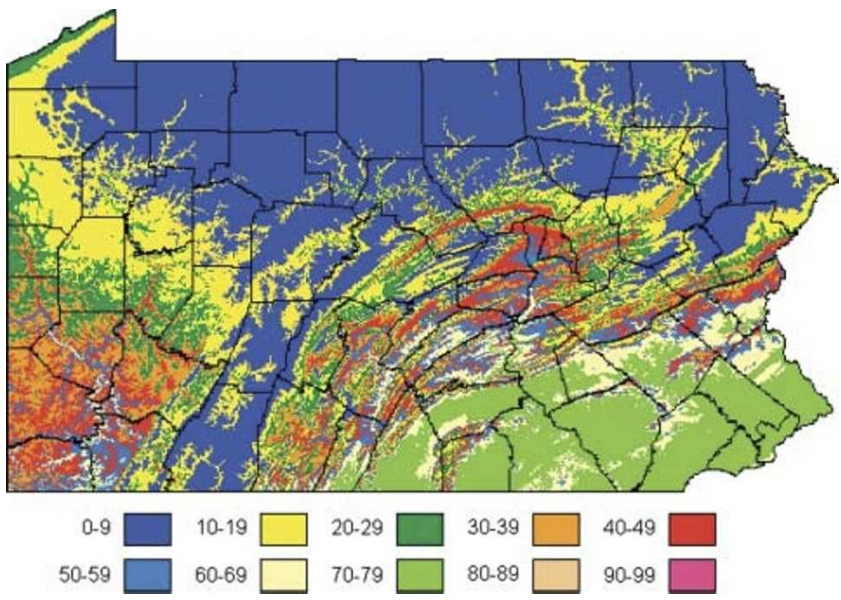

Fig. 7. Map showing predicted sweet corn infestation by european corn borer as of 25 Aug., based on 30-year averages ( $\mathrm{x}$-value) and the sigmoid function $\mathbf{y}=\mathbf{a}+\mathbf{b} \times\left(\exp \left\{-0.5[(\mathrm{x}-\mathrm{c}) / \mathrm{d}]^{2}\right\}\right)$, where $\mathbf{a}=0.0589, \mathrm{~b}=$ $0.7311, \mathrm{c}=1402.5667$, and $\mathrm{d}=139.4216$. can lead to general predictions, at planting, of harvest dates and anticipated european corn borer larval infestations.

Predicting actual infestation levels would likely be the most challenging, because of variability in weather, climate, geography, voltinism (Eckenrode et al., 1983), and widespread planting of corn expressing the insecticidal protein of Bacillus thuringiensis (Ostlie et al., 1997). It is therefore quite likely that predictions of larval infestation-levels (Fig. 7; Table 2) will be variable and will need be adapted to local conditions. Despite this likelihood of different geographic regions having different predictions of actual levels of infestations at harvest, evidence exists from the data of Ferro and Fletcher-Howell (1985) that these predictions may have the potential to lead to reasonable accuracy. Analyzing their data, the percentage of european corn borer infested sweet corn ears at harvest ( $y$-variable) as a function of day of the year (i.e., I July = 182), the nonlinear relationship was $\mathrm{y}=$ $\mathrm{a}+\mathrm{b} \times\left(\exp \left\{-0.5[(\mathrm{x}-\mathrm{c}) / \mathrm{d}]^{2}\right\}\right)$, with $\mathrm{a}=2.485 \pm 6.348, \mathrm{~b}=3001.103 \pm$ $61098.721, c=383.045 \pm 644.841$, and $\mathrm{d}=45.652 \pm 112.394$ (mean of parameter $\pm \mathrm{SE}$ ), with an overall mean square error $=4.386, \mathrm{~F}=79.36$ $(P<0.0001)$, and an $r^{2}$ value of 0.97 . We would expect this type of relationship to be stronger where there is a dominant voltine ecotype, such as was observed in these data from Ferro and Fletcher-Howell (1985).

Because these predictions of european corn borer at harvest for a site or landscape may allow a method for sweet corn producers to more 
accurately anticipate risk of european corn borer infestation at harvest, this approach may have implications in anticipating more optimal use of inputs such as scouting and insecticides (Dively, 1996; Flood et al., 1995 ) and biological control (Kuhar et al., 2002; Losey et al., 1995; Mertz et al., 1995) needed for a particular planting dates. Additionally, use of transgenic sweet corn hybrids expressing the toxin of $B$. thuringiensis have been shown to be extremely effective in controlling larval stages of Lepidoptera (Burkness et al., 2002; Dively, 2006). However, because transgenic seed is more expensive than nontransgenic seed (Dively, 2006), predicting harvest infestations may aid in more efficient use of this technology by optimizing its use during higher infestation periods. Dively (2006) has suggested using Bt sweet corn in later plantings because of higher risk of insect infestations.

This approach could also have potential in anticipating the scheduling of scouting activities. Spangler et al. (2003) found that $79 \%$ to $87 \%$ of the variability of european corn borer infestations (proportion of ears infested or larvae per ear) was attributed to eggs laid from anthesis to brown silk stages of sweet corn, and the highest correlation was with eggs laid from green tassel to green silk. Their results aligned with current recommendations (Dively, 1996; Flood et al., 1995). The approach we are proposing here is easily adapted to predicting when these critical periods are likely to occur before harvest, therefore allowing more efficient scheduling of scouting activities.

This research only addressed management of european corn borer. Because the other ear-infesting Lepidoptera (corn earworm fall armyworm) can often require more insecticide applications compared with european corn borer (Dively, 1996; Flood et al., 1995), the predictive system we propose is a supplement to existing management programs.

In general, we are proposing that the risk of infestation in sweet corn by european corn borer at harvest can be assessed at the time of planting based on degree-day accumulations, and that this approach has implications toward more effective insect pest management. By integrating relationships between plant (Arnold,
1974; Ritchie et al., 1992) and insect (Bessin, 2003; Glogoza and Boetel, 2005; Tollefson and Calvin, 1994) developmental rates, relating these to infestation levels and integrating these with technologies that allow prediction of degree-days for a site or landscape (Table 1, Figs. 4-7; Calvin, 2007), more accurate predictions of european corn borer infestations can be attained.

\section{Literature cited}

Andreadis, T.G. 1988. Management of first generation european corn borer, Ostrinia nubilalis, in early season, fresh market sweet corn in Connecticut. J. Agr. Entomol. 5:153-159.

Angel, J. 2008. What are heating/cooling/growing degree days? 12 May 2008. <http://www.sws.uiuc.edu/atmos/ statecli/FAQ/faq.htm>.

Arnold, C.Y. 1974. Predicting stages of sweet corn (Zea mays L.) development. J. Amer. Soc. Hort. Sci. 99:501-505.

Bessin, R. 2003. Predicting european corn borer development. University of Kentucky ENTFACT-106. 12 May 2008. <http://www.ca.uky.edu/entomology/ entfacts/efl06.asp>.

Burkness, E.C., W.D. Hutchison, R.A. Weinzerl, J.L. Wedberg, S.J. Wold, and J.T. Shaw. 2002. Efficacy and risk efficiency of sweet corn hybrids expressing a Bacillus thuringiensis toxin for Lepidopteran pest management in the midwestern US. Crop Prot. 21:157-169.

Calvin, D.D. 2007. Field crop information, insect prediction maps. 12 May 2008 <http://www.ento.psu.edu/extension/ field_crops/predictionmaps.htm $>$.

Calvin, D.D., M.C. Knapp, K. Xingquan, F.L. Poston, and S.M. Welch. 1986. Using a decision model to optimize european corn borer (Lepidoptera: Pyralidae) egg mass sampling. Environ. Entomol. $15: 1212-1219$.

Despins, J.L. and J.E. Roberts, Jr. 1984. Phenology of adult european corn borer (Lepidoptera: Pyralidae) in Virginia. J. Econ. Entomol. 77:588-590.

Dively, G.P. 1996. Northeast sweet corn action thresholds and decision-making guide, p. 87-92. In: R.G. Adams and J.C. Clark (eds.). Northeast sweet corn production and integrated pest management manual. Univ. Connecticut Coop. Ext., Storrs.

Dively, G.P. 2006. Does it pay to grow Bt sweet corn? 12 May 2008. <http:// www. glexpo.com/2006abstracts/Sweet Corn2006.pdf>

Eckenrode, C.J., P.S. Robbins, and J.T. Andolaro. 1983. Variation in flight patterns of european corn borer (Lepidoptera: Pyralidae) in New York. Environ. Entomol. 12:393-396.

Ferro, D.N. and G. Fletcher-Howell. 1985. Controlling european corn borer (Lepidoptera: Pyralidae) on successionally planted sweet corn in western Massachusetts. J. Econ. Entomol. 78:902-907.

Fleischer, S.J. 2003. Sweet corn insect pest monitoring system. 12 May 2008. $<$ http://www.pestwatch.psu.edu>.

Flood, B., R. Foster, and B. Hutchison. 1995. Sweet corn, p. 19-40. In: R. Foster and B. Flood (eds.). Vegetable insect management. Meister Publishing, Willoughby, $\mathrm{OH}$.

Glogoza, P. and M. Boetel. 2005. Corn insects of North Dakota affecting crop after emergence. 12 May 2008. <http:// www.ag.ndsu.edu/pubs/plantsci/row crops/e1300-12.gif>.

Holmstrom, K.E., M.G. Hughes, S.D. Walker, W.L. Kline, and J. IngersonMahr. 2001. Spatial mapping of adult corn earworm and european corn borer populations in New Jersey. HortTechnology 11:103-109.

Hutchison, W.D. and S.J. Wold. 2003. VegEdge web site and Minnesota vegetable IPM newsletter. 12 May 2008. $<$ http://www.vegedge.umn.edu>.

Kuhar, T.P., M.G. Wright, M.P. Hoffmann, and S.A. Chenus. 2002. Life table studies of european corn borer (Lepidoptera: Crambidae) with and without inoculative releases of Trichogramma ostriniae (Hymenoptera: Trichogrammatidae). Environ. Entomol. 31:482-489.

Losey, J.E., S.J. Fleischer, D.D. Calvin, W.L. Harkness, and T. Leahy. 1995. Evaluation of Trichogramma nubilalis and Bacillus thuringiensis in management of Ostrinia nubilalis (Lepidoptera: Pyralidae) in sweet corn. Environ. Entomol. $24: 436-445$.

Mason, C.E., M. Rice, D.D. Calvin, J.W. Van Duyn, W.B. Showers, W.D. Hutchison, J.F. Witkowski, R.A. Higgins, D.W. Onstad, and G.P. Dively. 1996. European corn borer: Ecology and management. North Central Regional Ext. Publ. no. 327. Iowa State University, Ames.

Mertz, B.P., S.J. Fleischer, D.D. Calvin, and R.L. Ridgway. 1995. Field assessment of Trichogramma brassicae (Hymenoptera: Trichogrammatidae) and Bacillus thuringiensis for control of Ostrinia nubilalis (Lepidoptera: Pyralidae) in sweet 


\section{Research Reports}

corn. J. Econ. Entomol. 88:16161625 .

Ostlie, K.R., W.D. Hutchison, and R.L. Hellmich. 1997. Bt corn and european corn borer: Long-term success through resistance management. NCR 602, University of Minnesota, St. Paul.

Pike, D. 2003. Sweet corn pest management strategic plan. 12 May 2008. $<$ http://pestdata.ncsu.edu/pmsp/pdf/ NCSweetcorn.pdf $>$.

Ritchie, S.W., J.J. Hanway, and G.O. Benson. 1992. How a corn plant grows. Iowa State Univ. Sci. Technol., Coop. Ext. Serv. Rpt. no. 48.
Royer, M.H., J.M. Russo, and J.G.W. Kelly. 1989. Plant disease prediction using a mesoscale weather forecasting technique. Plant Dis. 73:618-624.

Shelton, A.M. 1986. Management of Lepidoptera on processing sweet corn in western New York. J. Econ. Entomol. 79:1658-1661.

Spangler, S.M. and D.D. Calvin. 2000. Influence of sweet corn growth stages on european corn borer oviposition. Environ. Entomol. 29:1226-1235.

Spangler, S.M., D.D. Calvin, and M. Nemeth. 2003. Infestation of european corn borer (Lepidoptera: Crambidae) in sweet corn as predicted by time of oviposition. J. Econ. Entomol. 96:413-419.

Tollefson, J.J. and D.D. Calvin. 1994. Sampling arthropod pests in field corn, p. 433-474. In: L.P. Pedigo and D.D. Buntin (eds.). Handbook of sampling methods for arthropods in agriculture. CRC Press, Ann Arbor, MI.

U.S. Department of Agriculture. 2008. Crops and plants, vegetables, corn sweet. 15 June 2008. <http://www.nass.usda. gov/QuickStats/index2.jsp>. 